\title{
The Personal and the Professional: Assessing the Ambivalent Commitment to Racial Justice in the United States
}

\author{
Malcolm M. Feeley
}

$W_{\text {ick }}$

Lempert and I are the same age. As white males observing, confronting, and contemplating racial injustices, we have had different but parallel experiences. Our initial experiences with racial discrimination took place when we were young in the late 1940 s and early 1950 s, prior to the advent of the modern civil rights movement. He confronted it in New Jersey, and I did when I abruptly moved from Portland, Oregon's, integrated Grant Park area to Texas, where I attended segregated schools and had to listen to teachers explain why God had created the different races. We both saw matters in light of our parents' experiences and through their wise eyes. We both came of age in the wake of Brown v. Board of Education (1954). I saw the segregated school system in San Antonio quickly integrate, $\mathrm{K}$ through 12, in one fell swoop because the military threatened to pull the children of military personnel out of the public schools if it didn't. Our academic lives began in earnest in the 1960s just as the Second Reconstruction commenced. We now write as the Second Reconstruction has suffered an ignominious death. Indeed, the death knell of the Second Reconstruction was sounded just as it hit full stride, when at the signing of the 1964 Civil Rights Act, President Lyndon B. Johnson turned to Hubert Humphrey and observed, "I've just delivered the entire South to the Republicans for the next one hundred years." The prescience of this observation was revealed in the 1968 presidential election, and in every national election since. White Southerners have flocked to the Republican Party and, together with angry white voters across the country, constitute a sizeable electoral force that has transformed the party of Lincolnor at least one large wing of it - into a bastion of racial intolerance. In so doing it has all but squeezed out moderate Republicans, who while fiscally conservative are committed to civil rights.

Although the Second Reconstruction made overt racism socially unacceptable, it did little to root out the foundations of racism or to alter the institutional structures in which it can reside. Indeed, it may have aided the latter. Racism has adapted and 
persists in the Civil Rights Society as readily as it did in the era of Jim Crow after the end of the First Reconstruction. The War on Crime is one obvious adaptation, but so is the War on Welfare (in response to the War on Poverty). So, too, are our national urban policy that continues to neglect central cities, the unrelenting attack on judicial "activism," and the failure to make a massive commitment to improve our nation's public schools. Furthermore, even tentative steps in the right direction often produce frustrating if not counterproductive results. Bumiller (1988) has shown in her classic book, The Civil Rights Society, and many others have followed, that efforts grounded upon a tort-like notion that we live in a tolerant society are woefully inadequate. Discrimination, her work reveals, is everywhere, and requiring a victim to bear the burden of proof distorts the truth about the problem. (She and others have noted that the most effective civil rights act is probably the Voting Rights Act of 1965, which relies on easily identified objective measures, places the burden of proof upon state institutions, and relies upon federal officials for implementation.) Wilson (1978) and others have shown that antidiscrimination laws in housing and employment have had some effect, but at the same time they have allowed a small middle class to escape the black ghetto, thus leaving the remaining residents that much worse off. Bell (1987) has advanced the provocative thesis that blacks can only benefit from social policies to the extent that these policies also benefit whites, thus institutionalizing a cruel trickle-down policy that can only perpetuate racial inequality.

Lempert's essay is moving because it speaks from the heart, from personal and family experience. It also embraces something of a tragic view of the challenge of racial inequality. And it implicates us all, at least those of us who have lived through the era with him, have been involved with the Law \& Society Association (LSA) from near the outset, and were drawn to it for the same combination of scholarly and social justice reasons. The essay speaks about his formative experiences in childhood, his coming of intellectual age during the early days of the civil rights era, and his professional agenda since, all against the background of the social policies of the Second Reconstruction and research on their impacts. It certainly reveals that we need more Rick Lemperts. He is a prodigious scholar. He has made a contribution to two fields, legal scholarship and sociology, and has held central administrative positions in two departments at the University of Michigan, the Law School and the Department of Sociology, not to mention his work with the National Science Foundation (NSF), the National Research Council, and the LSA. Despite his many achievements, I have no doubt that Lempert's greatest professional pride is his research on affirmative action. He is right to be proud; his work has convinced 
skeptics in a way that most research does not. Modest to a fault, Lempert describes this work in his essay but characteristically understates his role in developing it and does not mention his many other related contributions.

His essay is an assessment of three things: his own personal response to the American tragedy of racial injustice, LSA's reaction to this tragedy, and the effects of the social policies that were adopted in the nation's commitment to racial equality. In this threepart discussion, the personal stands out (though I'm not sure that he would accept the tripartite form I've imposed on his essay). We see a committed scholar and see how this commitment emerged. We see a stream of his socially relevant research that has made a difference, or at least as much a difference as any single scholarly effort is likely to produce. Combining the sociologist's skills in research and data analysis with a lawyer's concern with social justice and the need to formulate it in practical terms amenable to legal discourse, he has made a difference.

His assessment of the LSA's and the Law $\mathcal{E}^{2}$ Society Review $(L S R)$ 's focus on the issue of racial equality is mixed. Of course he recognizes that LSA is not the Urban Institute, and $L S R$ is not the Urban Institute Press. Neither was created with a mandate to pursue a single mission, however important. LSA and LSR are scholarly enterprises that respond to the multiplicity of interests of their members and readers and thus must explore the range of ways that law and society are imbricated and constitutive of one another. Still, racial injustice is the American tragedy, and racism is laced into the fabric of society through law. Lempert gently reminds us that this issue has not been dealt with in the Association in proportion to its magnitude as a social evil. (There is one more American-in my view, the only other true-tragedy, the genocide of Native Americans, but it remains such a horrible chapter in our history that it has yet to be seriously confronted by large numbers of academics in mainstream scholarly outlets.)

Neither Lempert, I am sure, nor I, want to ascend a pulpit and preach to the converted about the need for more research on the failures to achieve-indeed, seriously pursue-the aspiration of equal justice that is part of the American creed. In fact, as I argue presently, I think it may be useful to approach some of these issues indirectly. But I do want to note two events in the life of the Association and $L S R$ that have been important to me and that also reveal the weakness of the Association. I was born into LSA, as it were. While in graduate school at Minnesota, two of my professors, political scientist Sam Krislov and anthropologist Ad Hoebel, recommended me to Red Schwartz, then a professor of sociology at Northwestern and the founding editor of $L S R$, for a summer position as a student editor. Along with several other law and 
graduate students from around the country, I spent the summer of 1967 working in Evanston editing Volume 2, No. 1 of the Review. The journal had just begun and was not yet swamped with submissions, so like editors of all new journals, Red had cast about for a symposium to fill the pages. He found a treasure trove: reports on efforts to combat de facto segregation in Northern schools that had been commissioned by the U.S. Commission on Civil Rights. The common feature of the several case studies we edited was the effort to desegregate schools in which there had been no legal finding of de jure segregation. Citizens leading the efforts in these communities were ahead of the curve (though I should mention that their activities all commenced in the mid-1960s, fully 10 years after Brown!) and wanted to use racial classifications in the effort to achieve greater racial balances in their cities.

The reports were written by eight (then young) hotshot law professors, some of whom later became my colleagues at Berkeley and Stanford (Jack Coons; Michael Heyman, who eventually became Berkeley's chancellor; and John Kaplan). It was a challenging task; these guys wrote like law professors-long-winded, masses of unnecessary footnotes, sloppily presented data, not very wellorganized analysis, and certainly no coordinated parallel analysis across the eight cities. Our charge from Red: Take the 150-plus page reports, find important common themes, boil them down by 75 percent, and present a series of case studies amenable to comparative analysis. Then analyze them comparatively. And use a social science and not a law review citation system to boot! In doing all this we incurred the collective wrath of the hotshot young law professors. But we slowly won them over by pointing out that none of them would be published in the Review if they insisted upon the original lengths of their manuscripts, by playing them off against each other (he agreed to cut, so why won't you?), and by declaring that we had discovered important common themes that would be highlighted only in shorter, more focused pieces-and finally by reminding them that they could always publish the longer version of their 150-page monstrosities as law reviews. (I don't think any of them ever did, and for good reason.)

The result was the publication of a symposium issue on school desegregation that appeared in $L S R$, and then a short time later as a book, Affirmative School Integration: Efforts to Overcome De Facto Segregation in Urban Schools, edited by Roscoe Hill and myself, and with an introduction by James Coleman (1968). It is I think the first study to explore efforts to combat de facto segregation, or at least school segregation that did not have the direct imprint of the law on it. Periodically I reread the volume and don't know whether to laugh or cry. The naïvete of the authors and us editors is in retrospect more than embarrassing. The authors, caught up in the 
headiness of the times and celebrating the goodwill of those communities that had taken steps to overcome de facto segregation in the absence of a court order directing them to, were writing the end of history. Chicago was to establish school attendance areas by creating pie-shaped slices with the tips on the lake and broadening out as they reached the suburbs, so that each zone would reflect the city as a whole. Evanston, small and compact, had solved its problems easily enough by shifting a few boundaries and instituting creative transfer polices for students and faculty. Berkeley's plan was similar to Chicago's: Establish ribbon-like attendance zones running from the bay into the flats up into the hills and continue to maintain one huge high school, thus assuring a cross-section of students in every school. Blacks in San Francisco were concentrated in a central location in the center of the city, so diagonal attendance zones would disperse those in the center and equalize racial balance. We are all familiar with the subsequent racial polarization in Chicago. I later got to know the judge and some of the lawyers who were involved in the 25-year litigation battle to desegregate San Francisco schools. My kids went to Berkeley public schools for a while, though for the past 30 years in Berkeley most middle-class white (and many black) kids whose parents could afford it have opted for private schools. How naïve we were.

But we were not wholly off the mark. Our analysis of the case studies examined the problems caused by the ambiguity in the law with respect to the use of racial categories for benign purposes. We argued for the need to have a clear and unambiguous policy supporting the use of race-based classifications, arguing that without it, opponents would succeed outright or be able to drag issues out endlessly. Furthermore, we noted, the pursuit of racial equality required moving beyond a focus on findings based on narrowly conceived de jure racial segregation. This of course has been one of the central contentions over the past 40 years, until affirmative action was all but killed by popular opinion and five Supreme Court justices. But Lempert's work stands as testimony that such efforts can yield dramatic and positive results.

Our burst of naïve enthusiasm took place at the dawn of the Second Reconstruction. Now that is has drawn to a close, what else has the Association done? How can we assess it? Over the years of course LSA has fostered symposia at its annual meetings and mounted its own affirmative action effort to draw more black, Asian, and Latino scholars into the Association and its meetings, and onto the pages of $L S R$. I suspect that it has done more for the cause of racial equality than most discipline-based national associations, which is to say some, but not much. However, institutionally, at the end of the Second Reconstruction, the Association has mounted two major enterprises, both supported by the NSF. One is the 
Fellowship Program, jointly sponsored by LSA and the American Bar Foundation (ABF), and funded by the NSF and the ABF. This program allows a handful of graduate students to spend a year working with mentors at the $\mathrm{ABF}$ on issues related to the causes and conditions of inequality. Support for this was obtained after a huge and sustained effort by a great number of people in the Association, too many to identify individually. One hopes that this program will facilitate the careers of a number of young scholars whose work will be dedicated to the pursuit of these issues. A related recent effort by the Association was the "The Paradoxes of Race, Law and Inequality in the United States" symposium, overseen by LSR editor Carroll Seron, who organized a conference at UC Irvine and then after review and revision led to the publication in this issue of the best of these papers. It is, I am pretty sure, only the second symposium issue of the Review that has focused on race. I'm afraid that the articles in Volume 2, No. 2 and Volume 44, No. 3-4, together constitute a significant portion of all the articles ever published in $L S R$ whose focus is primarily on racial inequality. Certainly the figures Lempert cites in this regard do not reveal something to the contrary. One hopes that 45 more years do not have to elapse before the next symposium on the American tragedy is published.

Lempert's third concern is with the effects of the social policies that were adopted during the Second Reconstruction, or more precisely with the social science research that has examined the impact of various civil rights policies that were adopted in the 1960s and 1970s. Much of his essay is devoted to summarizing the findings and reporting on the "fragility of progress."

To quickly summarize some of the highlights:

Income: "Data suggest the fragility and unevenness of progress," and marginal improvements have "begun to reverse coincident with the beginning of the Bush administration" (p. 444, this issue).

Wealth: "[as of 2004] the median black household's liquid financial wealth was $\$ 300$, while the median white family had a bit more than $\$ 36,000$ it could draw on" (p. 444, this issue).

Crime: "[as of 2001] 16.6 percent of all black males had spent at least some time in a state or federal prison. The comparable figure for white males is 2.6 percent ... the ratio of blacks to whites with prison experience was virtually unchanged from what it had been in $1974 \ldots$ blacks are, relatively speaking, considerably more likely than whites to be victims of violent crimes" (pp. 446-7, this issue).

Employment: "in every year from 1972 through 2007, black unemployment rates were not just higher than white unemployment rates, they were more than double" (p. 447, this issue). 
Education: In sharp contrast to 1960, when whites graduated high school at twice the rate of blacks, the two groups now graduate school at about the same rate, and "black education rates through college graduation and beyond have had an even steeper trajectory" (p. 449, this issue).

Political Office: "There has also been a substantial increase in the number of blacks elected to office over time [in large part, as a result of the Voting Rights Act of 1965]" (p. 450, this issue).

Attitudes: "We can see substantial attitude change," but subtle forms of racism and unconscious racism persist. "Blacks are disadvantaged not just because of their educational status ... or greater likelihood of criminal convictions ... they are disadvantaged because they are black" (pp. 450-1, this issue).

Behavior: Lempert reviews the research racial discrimination conducted by Pager (2003; see also 2007) and others, as well as more work summarized by Massey and Denton (Massey 2007; see also Massey \& Denton 1993) that reports frightening levels of subtle and unconscious racism in people like you and me, who are readers of this essay.

That was Lempert's wind-up; what is his delivery? In noting the marked improvements in political participation and political office-holding, Lempert emphasizes how effective the Voting Rights Act has been, and with respect to achievements in higher education, how effective affirmative action programs have beenwere, past tense, now for the most part. He notes that the greatest gains in employment have been achieved in the South, where the original baseline was the lowest and job growth has been the highest over the past 40 years. Some cause for joy, but not much.

When some of the figures Lempert relies upon are disaggregated or put in somewhat different context, things look bleaker. Income and wealth are to some extent relative; it depends upon where you live-Chicago or rural Tennessee. Employment is not always employment; just as blacks in large numbers made it to the industrial heartland, the bottom fell out of industrial production, the Rust Belt materialized, and blue collar jobs were replaced by lower paying service sector jobs. Similarly, just as blacks obtained union membership and access to unionized jobs, the bottom fell out of unionization (Frymer 2008). Poverty-alleviation programs and health care - never generous in our begrudging welfare statehave become far worse (Handler \& Hasenfeld 2007). More recently with workfare, definitions of poverty have been lowered, benefits slashed, and eligibility requirements tightened. No one now seriously thinks that a destitute family can survive on welfare alone, however frugal they are. Everyone must cheat. We have knowingly 
created a new class of criminals who are disproportionately black and female. Educational improvements are encouraging, but the greatest improvements are for those with the highest education, suggesting that a tiny minority of blacks can make it and obtain professional jobs (though here they continue to experience invisible barriers). Crime figures are devastating and have gotten worse over the years; they are even more frightening than Lempert suggests. As noted above, Lempert reports that 16.6 percent of all black males spend some time in prison, in contrast to 2.6 percent of white males (p. 446, this issue). But when class and locality are controlled for, the differences explode. Incarceration figures for poor black males who reside in city centers can exceed 60 percent (Wacquant 2009:149).

The conditions that Lempert describes (and at times understates) are sobering, and his essay ends with a somber tone. The great gulf between black and white and the persistence of that gulf, in contrast to the erosion of such differences over time for the various immigrant groups to this country, should generate a sense of despair and urgency. They are similar to the vast inequalities in some underdeveloped countries - the Philippines, Argentina, Mexico, all of which could easily descend into political chaos. Indeed, the situation in the United States is more dire because the American situation contains the twin combustibles of inequalities, class and race.

Furthermore, the problems, the worst of the problems, are not just or even a byproduct of casual or unintentional racism. Rather they are a combination of casual racism and planned, deliberate social policy where the results were both foreseeable and foreseen. The draconian cuts in welfare benefits were not a by-product of rampant inflation that shrank the purchasing power of the dollar. They were a deliberate action intended to transform welfare into workfare with a new lower definition of poverty and tighter eligibility requirements. And this was introduced not by meanspirited Republicans, but by America's first "black" President, Democrat Bill Clinton. Similarly, as Massey and Denton (1993) document in their landmark book, American Apartheid, the destitution of the central cities with their concentration of poor and racial minorities was not a product of oversight or benign neglect. It was the consequence of the deliberate actions of local, state, and national officials. From World War II until today, our public officials have chosen to subsidize housing construction in the suburbs, give preference to highway systems that connect central cities to the suburbs, build segregated subsidized housing, and direct wellpaying job creation to the suburbs. In the 1960 s and 1970 s, even as congressional judiciary committees were fashioning fine-sounding and well-intended civil rights bills, other congressional committees 
dealing with housing, transportation, banking, insurance, and industry were fashioning other much more far-reaching policies that, quietly and with no fanfare and little notice, cut sharply in the opposite direction. Even though the worst of these policies have now been at least partially reined in, it now may be too late. The nation's entire postwar infrastructure that reinforces segregation has been set in place and will remain fixed for the next 50 to 100 years, until possibly a third set of civil disturbances and a Third Reconstruction may set in motion actions to deal with a by-then crumbling infrastructure.

What holds for the development of American infrastructure also holds for American crime policies. Democrats have been willing to "out-crime" Republicans and thus drive up incarceration rates for blacks. (In 1992, in Cummins Prison Farm in Arkansas, I spent half an hour talking to a black man who had been sentenced to death and who had turned himself into a child-like idiot when trying to blow out his brains before he was apprehended. Two days after my conversation with him, presidential candidate Bill Clinton, along with a television crew, stood 10 feet away from him and witnessed his execution.) Indeed, crime only ceased (if it has) being a major national issue when fiscal conservatives came to realize that there is a near-inexhaustible number of people to incarcerate, and when they found that the Democrats had become as adept as Republicans in Willy Hortoning their opponents.

The problems of racial inequality are of gargantuan proportion, and research by Wilson $(1978,1987)$, Massey and Denton (1993), Wacquant (2009), Fiss (2003), and many others reveal that the Second Reconstruction may not even have accomplished very much. In his recent essay, A Way Out: America's Ghettos and the Legacy of Racism, Fiss (2003) implicitly acknowledges that a vigorous ideological commitment to integration through law has failed. Indeed, he agrees with Wilson and Massey and Denton, and others, that the partial success of the integration ideal has unwittingly made a great many blacks worse off. Antidiscrimination laws have provided a way out of the segregation ghetto for a handful of blacks, for whom the integration ideal is now a reality. But as Fiss and others have ruefully observed, this ideal is a hoax for vast numbers of other blacks. Now, inner cities are not only segregated by race, they are also segregated by race and class, such that racial isolation in many areas has reached or is near all-time highs. Since Wilson's, Massey and Denton's, and Fiss's work, this nation has taken a giant step backward in its never very robust commitment to social justice. With the rise of neo-liberalism, this commitment has shrunk even more; the state has become something of a police state, both figuratively and literally, as it has transformed social welfare commitments into an extended reach of the criminal process. 
Fiss's response to this problem is to propose a massive Marshall Plan for inner cities-not to "renew" the inner city, but to allow residents to move out and to transform it entirely. It is an ambitious plan that would require trillions of federal dollars to effect. Strikingly bold, it has been heralded by some as a brilliant vision of the way out of our American dilemma, and disparaged by others as paternalistic and antithetical to American liberalism. Whatever it is, it is an admission by one of America's great champions of the Constitution and civil rights laws that striking down legal barriers as the way to assimilation has failed.

On a practical level, Fiss's plan faces two challenges. First is the challenge of will: Is there enough political courage, along with sufficient resources, to embrace something so bold? Maybe, but the march of contemporary political history is in precisely the opposite direction. Fiss has always had something of the prophet's demeanor; a Moses pointing to the promised land he cannot enter. But the sad truth is that his idea seems more like a bad joke than a sensible plan. Second is the challenge of doctrine: Does legal doctrine permit such action? Forty-five years ago, as a student editor on $L S R$, I along with my colleagues wrote that nothing much of substance could happen unless policy makers - courts, President, Congress, the public - could embrace the idea of race-conscious policies to combat instances of de facto racial inequality. That issue tied policy makers up in knots for years and has recently been definitively answered in the negative. Thus the resounding answer to both issues posed by Fiss's analysis is no. As a polity, we lack political will even to place such proposals on the public agenda. Indeed, his ideas may even seem preposterous in an era where America's number one social policy to deal with race is expanded reliance on imprisonment, even as crime rates plummet. But they are preposterous for another reason as well. The doctrinal door has been shut on them for at least a generation. Even if effected they could only succeed if they were to become so generalized and inclusive so as to completely lose their moral urgency with respect to targeting the evils of racism. If implemented, they would become one more program for the underprivileged that would instead benefit the middle class.

Thirty years ago, when conditions for black Americans were not so dire as they are now and when issues of racism commanded greater public attention, Fiss's colleague, the late Boris Bittker (1979), wrote a small and impassioned book calling for black reparations. That book was ignored from the day it went into print. Fiss's much more recent assessment has experienced a similar fate.

This is a bleak portrait, and I would be pleased for someone to show me how I have drawn the wrong conclusions. But even if I 
am off the mark, I doubt that I am far off. What does this suggest for members of the Law \& Society Association? I am loath to offer advice, as my first principle of scholarship is that people should follow their hearts and do what they are interested in. But I must admit that I do question the value of an emphasis on explicitly policy-directed research. I do this not because I think it is selling out, or dishonorable, or ineffective-Lempert's research, and the research of many more law and society scholars, proves the contrary. It can influence, it can be effective, it can make a difference.

Still, I would like to endorse another style of research, one that is at once empirically rigorous but at the same time embraces social theory and not policy impact as its frame of reference. Not only have popular culture and policy discourse eschewed anything resembling class analysis or social theory, so too has much sociolegal research. And even when it has, it has often been of an ethereal sort, floating round in clouds of "late modernity" and the like, and several stages removed from systematic empirical inquiry. Locating the particular in light of the whole or even part of the whole is, I think, helpful in gaining or maintaining one's bearings. More fine-grained policy-relevant analysis may be exciting, and it may even help ameliorate real social problems, but it may not help us see clearly how the particular affects the general.

\section{References}

Bell, Derrick (1987) And We Are Not Saved: The Elusive Quest for Racial Justice. New York: Basic Books.

Bittker, Boris (1979) The Case for Black Reparations. New York: Random House.

Bumiller, Kirstin (1988) The Civil Rights Society: The Social Construction of Victims. Baltimore: Johns Hopkins Univ. Press.

Fiss, Owen (2003) A Way Out: America's Ghettos and the Legacy of Racism. Princeton, NJ: Princeton Univ. Press.

Frymer, Paul (2008) Black and Blue: African Americans, the Labor Movement, and the Decline of the Democratic Party. Princeton, NJ: Princeton Univ Press.

Handler, Joel, \& Yeheskel Hasenfeld (2007) Blame Welfare, Ignore Poverty and Inequality. New York: Cambridge Univ. Press.

Hill, Roscoe, \& Malcolm Feeley, eds. (1968) Affirmative School Integration: Efforts to Overcome de facto School Segregation. Beverly Hills, CA: Sage Publications.

Massey, Douglas (2007) Categorically Unequal: The American Stratification System. New York: Russell Sage Foundation.

Massey, Douglas, \& Nancy Denton (1993) American Apartheid: Segregation and the Making of the Underclass. Cambridge, MA: Harvard Univ. Press.

Pager, Devah (2003) "The Mark of a Criminal Record," 108 American J. of Sociology 937-75.

(2007) Marked: Race, Crime and Finding Work in an Era of Mass Incarceration. Chicago: Univ. of Chicago Press.

Wacquant, Loic (2009) Punishing the Poor. Durham, NC: Duke Univ. Press. 
Wilson, William Julius (1978) The Declining Significance of Race: Blacks and Changing American Institutions. Chicago: Univ. of Chicago Press.

(1987) The Truly Disadvantaged: The Inner City, the Underclass, and Public Policy. Chicago: Univ. of Chicago Press.

\section{Case Cited}

Brown v. Board of Education, 347 U.S. 483 (1954).

\section{Statutes Cited}

Civil Rights Act 1964 (Pub.L. 88-352, 8 Stat. 241).

Voting Rights Act 1965 (42 U.S.C. sec. 1973-aa6).

Malcolm M. Feeley is Claire Sanders Clements Dean's Professor, Jurisprudence and Social Policy Program, Boalt Hall School of Law, University of California at Berkeley. 